\title{
Nitrogen limitation constrains sustainability of ecosystem response to $\mathrm{CO}_{2}$
}

\author{
Peter B. Reich ${ }^{1}$, Sarah E. Hobbie ${ }^{2}$, Tali Lee ${ }^{1,3}$, David S. Ellsworth ${ }^{4}$, Jason B. West ${ }^{2}$, David Tilman ${ }^{2}$, \\ Johannes M. H. Knops ${ }^{5}$, Shahid Naeem ${ }^{6} \&$ Jared Trost $^{1}$
}

Enhanced plant biomass accumulation in response to elevated atmospheric $\mathrm{CO}_{2}$ concentration could dampen the future rate of increase in $\mathrm{CO}_{2}$ levels and associated climate warming. However, it is unknown whether $\mathrm{CO}_{2}$-induced stimulation of plant growth and biomass accumulation will be sustained or whether limited nitrogen $(\mathrm{N})$ availability constrains greater plant growth in a $\mathrm{CO}_{2}$-enriched world ${ }^{1-9}$. Here we show, after a six-year field study of perennial grassland species grown under ambient and elevated levels of $\mathrm{CO}_{2}$ and $\mathrm{N}$, that low availability of $\mathrm{N}$ progressively suppresses the positive response of plant biomass to elevated $\mathrm{CO}_{2}$. Initially, the stimulation of total plant biomass by elevated $\mathrm{CO}_{2}$ was no greater at enriched than at ambient $\mathrm{N}$ supply. After four to six years, however, elevated $\mathrm{CO}_{2}$ stimulated plant biomass much less under ambient than enriched $\mathrm{N}$ supply. This response was consistent with the temporally divergent effects of elevated $\mathrm{CO}_{2}$ on soil and plant $\mathrm{N}$ dynamics at differing levels of $\mathrm{N}$ supply. Our results indicate that variability in availability of soil $\mathrm{N}$ and deposition of atmospheric $\mathrm{N}$ are both likely to influence the response of plant biomass accumulation to elevated atmospheric $\mathrm{CO}_{2}$. Given that limitations to productivity resulting from the insufficient availability of $\mathrm{N}$ are widespread in both unmanaged and managed vegetation ${ }^{5,7-9}$, soil $\mathrm{N}$ supply is probably an important constraint on global terrestrial responses to elevated $\mathrm{CO}_{2}$.

Continued emissions of $\mathrm{CO}_{2}$ by the burning of fossil fuel are expected to increase global atmospheric $\mathrm{CO}_{2}$ concentrations and surface temperatures significantly ${ }^{1}$. These changes will occur much more rapidly if the terrestrial or oceanic carbon sinks weaken in the future. However, predicting future atmospheric $\mathrm{CO}_{2}$ concentrations is hampered by uncertainties surrounding biospheric responses to elevated $\mathrm{CO}_{2}$, such as the possibility that soil $\mathrm{N}$ availability restricts the magnitude of $\mathrm{CO}_{2}$-induced biomass enhancement ${ }^{4-8}$. However, the importance of, and the mechanisms underlying, this limitation to the $\mathrm{CO}_{2}$ fertilization effect is a matter of debate ${ }^{2,3,7,8,10-12}$. This is not surprising, because even with widespread $\mathrm{N}$ limitation of net primary production in terrestrial ecosystems ${ }^{13}$, the nature, timing and predictability of $\mathrm{N}$ constraints on ecosystem $\mathrm{C}$ accumulation remain unclear ${ }^{2,6,8,11}$.

Multiple-resource-limitation theory provides a variety of mechanisms by which low $\mathrm{N}$ availability potentially limits the enhancement of biomass accumulation in response to elevated $\mathrm{CO}_{2}$, but not all models agree that this will occur ${ }^{2,3,10,14,15}$. At elevated $\mathrm{CO}_{2}$, low supply of $\mathrm{N}$ in the soil could limit the leaf area for intercepting light, limit the capacity of plants to fix $\mathrm{CO}_{2}$ photosynthetically, or lead to diminishing plant $\mathrm{N}$ availability over time through long-term soilplant $\mathrm{C}$ and $\mathrm{N}$ dynamics ${ }^{2-4,8,11,15,16}$. Each of these, or their combination, could diminish biomass response to elevated $\mathrm{CO}_{2}$. Therefore, a large increase in biomass accumulation under elevated $\mathrm{CO}_{2}$, often observed in short-term experiments, may not be sustained over the long term in natural systems given the $\mathrm{N}$ limiting conditions that predominate in both unmanaged and managed vegetation ${ }^{5,7,8}$.

Much research has addressed the response of $\mathrm{N}$ availability to elevated $\mathrm{CO}_{2}$, but findings have been inconsistent. Soil $\mathrm{N}$ availability has been observed to decrease under elevated $\mathrm{CO}_{2}$, but it has also been observed to remain stable or increase $e^{8,12,16-19}$. Moreover, results from studies that manipulated both $\mathrm{CO}_{2}$ and $\mathrm{N}$ are variable in terms of whether biomass accrual under elevated $\mathrm{CO}_{2}$ is affected by $\mathrm{N}$ supply ${ }^{5,6,9,18,20-22}$. The inconsistency of such responses may reflect inconsistent responses of soil $\mathrm{N}$ availability to elevated $\mathrm{CO}_{2}$, but additionally they may reflect variation in nutrient-use efficiency, stoichiometry or soil microbial processes that may eliminate or delay the impact of $\mathrm{N}$ limitation on the elevated $\mathrm{CO}_{2}$ response ${ }^{2,8,12}$.

Most experiments that have manipulated $\mathrm{CO}_{2}$ and $\mathrm{N}^{5,6,18,20-22}$ have been short in duration ( 3 years or less), which limits their utility in understanding interactions that are predicted to occur over longer time frames ${ }^{2,3,8,15}$. Despite the importance of understanding $\mathrm{CO}_{2} \times \mathrm{N}$ interactions, to our knowledge there are only three replicated field experiments in the world that have manipulated both $\mathrm{CO}_{2}$ and $\mathrm{N}$ supply for more than three years (including ours reported here). Two of these experiments are relevant to natural systems (early results are reported in refs 6,23 ) and one to intensively managed agricultural systems (long-term results are reported in ref. 9). In our experiment (called BioCON) we grew 296 field plots containing different numbers (1, 4, 9 or 16 species) and combinations of perennial grassland species under ambient and elevated $\left(560 \mu \mathrm{mol} \mathrm{mol}^{-1}\right)$ atmospheric $\mathrm{CO}_{2}$ and with either ambient or enriched soil $\mathrm{N}$ supply (ambient and enriched with $4 \mathrm{~g} \mathrm{~N} \mathrm{~m}^{-2} \mathrm{yr}^{-1}$ as $\mathrm{NH}_{4} \mathrm{NO}_{3}$ ). A total of 16 native or naturalized species were used in the study, four each from four functional groups (legumes, non-leguminous forbs, $\mathrm{C}_{3}$ grasses and $\mathrm{C}_{4}$ grasses). The main effects of diversity and interactions with $\mathrm{CO}_{2}$ and $\mathrm{N}$ were addressed previously ${ }^{18,23}$. We proposed that biomass accumulation of plants growing in ambient, $\mathrm{N}$-poor soil would be less responsive to elevated $\mathrm{CO}_{2}$ than would biomass of plants grown in $\mathrm{N}$-enriched soil. The contrasting high versus low levels of $\mathrm{N}$ supply in our study are broadly consistent with the global range in both rates of $\mathrm{N}$ supply in unfertilized soils and in annual $\mathrm{N}$ deposition ${ }^{13,24}$.

During the six years of the study, the stimulation of plant biomass accumulation by elevated $\mathrm{CO}_{2}$ became continuously weaker under ambient $\mathrm{N}$ supply than under enriched $\mathrm{N}$ supply (Fig. 1). Both $\mathrm{CO}_{2}$ and $\mathrm{N}$ generally stimulated biomass accumulation (Fig. 1, Table 1), and overall biomass levels declined after the first year and then varied over time. However, for the entire period there was a significant 


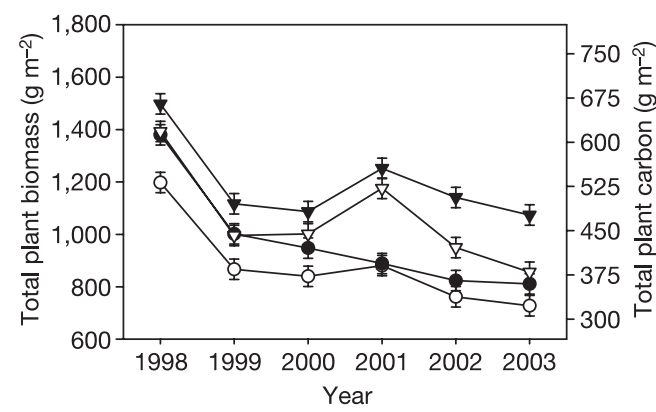

Figure 1 | Effects of $\mathrm{CO}_{2}$ and $\mathbf{N}$ on total plant biomass over time. a, Total plant biomass (above-ground plus $0-20 \mathrm{~cm}$ below-ground) and carbon at ambient and elevated $\mathrm{CO}_{2} \times \mathrm{N}$ levels from 1998 to 2003. Data were pooled across diversity treatments, and each point shows the annual mean (plus standard error) of 74 plots sampled twice per year. There was a significant interaction (Table 1) between $\mathrm{CO}_{2}, \mathrm{~N}$ and year $(P=0.0013)$, plus significant main effects $(P<0.05)$ of year, $\mathrm{CO}_{2}$ and $\mathrm{N}$. Open circles, ambient $\mathrm{CO}_{2}$ and ambient $\mathrm{N}$; filled circles, elevated $\mathrm{CO}_{2}$ and ambient $\mathrm{N}$; open triangles,
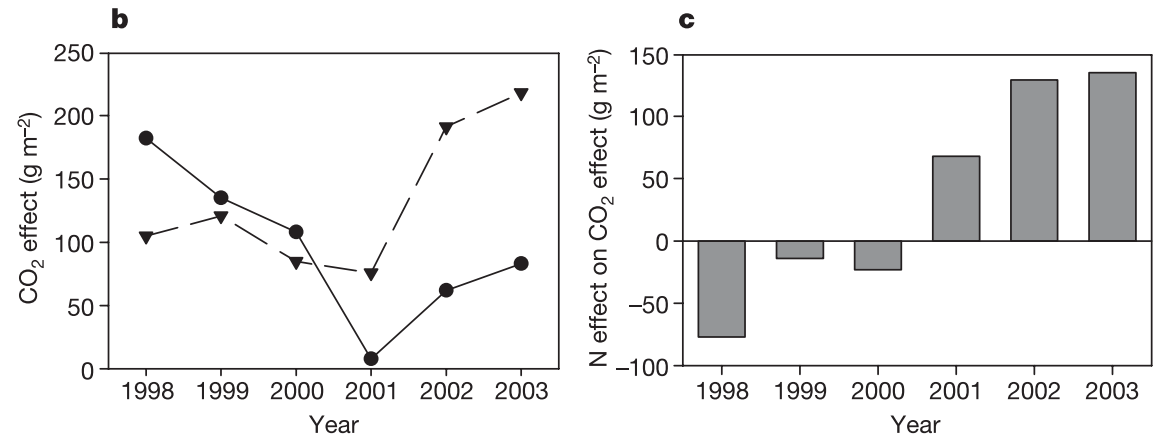

ambient $\mathrm{CO}_{2}$ and enriched $\mathrm{N}$; filled triangles, elevated $\mathrm{CO}_{2}$ and enriched $\mathrm{N}$. b, The effect of $\mathrm{CO}_{2}$ on total biomass: the $\mathrm{CO}_{2}$ enhancement (assessed as (value at elevated $\mathrm{CO}_{2}$ ) minus (value at ambient $\mathrm{CO}_{2}$ )) at ambient (circles) and enriched (triangles) $\mathrm{N}$ supply each year. c, The effect of $\mathrm{N}$ availability on the $\mathrm{CO}_{2}$ biomass effect, defined as the difference between the $\mathrm{CO}_{2}$ effect at enriched $\mathrm{N}$ and that at ambient $\mathrm{N}$, namely $\left(\mathrm{CO}_{2}\right.$ effect at enriched $\left.\mathrm{N}\right)$ minus $\left(\mathrm{CO}_{2}\right.$ effect at ambient $\left.\mathrm{N}\right)$.

temporal shift in the enhancement of total biomass by $\mathrm{CO}_{2}$ at ambient versus enriched $\mathrm{N}\left(P=0.0013\right.$ for the $\mathrm{CO}_{2} \times \mathrm{N} \times$ year interaction; Table 1, Fig. 1). This impact over time of $\mathrm{N}$ supply rate on response to elevated $\mathrm{CO}_{2}$ did not vary significantly with species diversity treatment. Data are therefore shown pooled across all species richness levels.

The significant three-way interaction involving $\mathrm{CO}_{2}, \mathrm{~N}$ and year occurred because the influence of enriched $\mathrm{N}$ supply on the $\mathrm{CO}_{2}$ response shifted in direction and grew larger with time (Fig. 1b, c, Table 1). The stimulation of total biomass by elevated $\mathrm{CO}_{2}$ was higher at ambient $\mathrm{N}$ than at enriched $\mathrm{N}$ each year from 1998 to 2000 (Fig. 1b), although for each year analysed individually there was no significant effect of $\mathrm{N}$ on the elevated $\mathrm{CO}_{2}$ response. However, in 2001, 2002 and 2003 the sign of the $\mathrm{CO}_{2} \times \mathrm{N}$ interaction switched: stimulation of total biomass by $\mathrm{CO}_{2}$ was greater at enriched $\mathrm{N}$ supply than at ambient $\mathrm{N}$ supply (statistically significant $\mathrm{CO}_{2} \times \mathrm{N}$ interaction in 2002 and 2003; $P<0.05$ ). For example, in 2002 and 2003, respectively, elevated $\mathrm{CO}_{2}$ increased biomass by 62 and $82 \mathrm{~g} \mathrm{~m}^{-2}$ at ambient $\mathrm{N}$ and by 191 and $219 \mathrm{~g} \mathrm{~m}^{-2}$ at enriched $\mathrm{N}$ (Fig. 1b). These correspond to $20-25 \%$ stimulation of biomass by elevated $\mathrm{CO}_{2}$ at enriched $\mathrm{N}$, compared with $8-12 \%$ stimulation at ambient $\mathrm{N}$.

The mechanisms responsible for the changes with time in the response of biomass accumulation to $\mathrm{CO}_{2}$ and $\mathrm{N}$ supply (Fig. 1) probably involve temporal heterogeneity in physiological acclimation, soil $\mathrm{C}$ and $\mathrm{N}$ mineralization and immobilization, and litter, root and soil organic matter decomposition and turnover ${ }^{12,18,25-28}$. For example, there were temporal changes in $\mathrm{CO}_{2} \times \mathrm{N}$ effects on total plant $\mathrm{N}$ pools and on net $\mathrm{N}$ mineralization rates in soil, including significant $(P<0.05)$ interactions between $\mathrm{CO}_{2}, \mathrm{~N}$ and year in both cases (Table 1). These were a consequence of elevated $\mathrm{CO}_{2}$ substantially increasing plant $\mathrm{N}$ pools and soil net $\mathrm{N}$ mineralization rates at enriched N supply in 2002 and 2003 (Supplementary Figs 1 and 2). These biomass and $\mathrm{N}$ cycle shifts in $\mathrm{CO}_{2} \times \mathrm{N}$ response over time could result in part from the immobilization of $\mathrm{N}$ into living tissues (below-ground turnover is about three years) and decomposing organic matter. Such $\mathrm{N}$ sequestration would probably have been enhanced in the treatment with elevated relative to ambient $\mathrm{CO}_{2}$ in the first two years of the study, because of higher biomass, initially higher biomass $\mathrm{C}: \mathrm{N}$ ratios, and greater labile $\mathrm{C}$ inputs ${ }^{28}$. The positive response to $\mathrm{CO}_{2}$ enrichment observed under ambient $\mathrm{N}$ during the first two years of the experiment may also be more characteristic of seedlings or juvenile plants than of mature, well-established plants.

Additionally, to test whether the accumulation of greater plant biomass at elevated $\mathrm{CO}_{2}$ than at ambient $\mathrm{CO}_{2}$ was due to a greater efficiency of use of $\mathrm{N}$ pools in $\mathrm{C}$ acquisition and accumulation, or to greater $\mathrm{N}$ pools, we examined the relationship between total plant biomass and total plant $\mathrm{N}$ across all plots. The slope of this relationship was greater at elevated $\mathrm{CO}_{2}$ than at ambient $\mathrm{CO}_{2}$ in 1998 and 1999 but not in 2000-2003 (Supplementary Table 1 and Supplementary Fig. 3 ; $\mathrm{CO}_{2}$ treatment $\times$ plant $\mathrm{N}$ pool $\times$ year interaction, $P<0.0001$ ). In 1998-1999, total plant biomass was about $15 \%$ higher at any given plant $\mathrm{N}$ pool at elevated $\mathrm{CO}_{2}$ than at ambient $\mathrm{CO}_{2}$. This $\mathrm{CO}_{2}$-enhanced $\mathrm{N}$ use efficiency disappeared with time: from 2000 to 2003 plots with elevated $\mathrm{CO}_{2}$ tended to occupy positions higher up on the same biomass $-\mathrm{N}$ relationship. These results indicate that in 1998-1999, stimulation of biomass accumulation by elevated $\mathrm{CO}_{2}$ might have been related to increased efficiency of physiological $\mathrm{N}$ use, whereas in later years the $\mathrm{CO}_{2}$ stimulation of biomass was associated with shifts in total plant $\mathrm{N}$ availability and accumulation.

We conclude from the results of our study that long-term biomass accumulation was influenced by the relative availability of $\mathrm{CO}_{2}$ and $\mathrm{N}$, with ambient $\mathrm{N}$ supply gradually limiting the potential biomass accumulation in response to elevated $\mathrm{CO}_{2}$, and enriched $\mathrm{N}$ supply gradually stimulating this response. These responses were similar for simple monocultures and complex mixtures. Moreover, even the plots with legumes, generally considered responsive to elevated $\mathrm{CO}_{2}$ independently of $\mathrm{N}$ supply $\mathrm{y}^{26,29,30}$, did not respond differently in terms of $\mathrm{CO}_{2} \times \mathrm{N}$ interactions than plots without legumes. In separate analyses of variance there was no significant interaction of $\mathrm{CO}_{2} \times$ $\mathrm{N} \times$ year with the presence or abundance of legumes or Lupinus (the most abundant legume) (Supplementary Table 2). Thus, the presence of legumes did not prevent the gradual development of a diminished elevated $\mathrm{CO}_{2}$ biomass response at ambient $\mathrm{N}^{30}$.

Our results are consistent with and extend previous experimental studies of $\mathrm{CO}_{2} \times \mathrm{N}$ interactions in agricultural and forest plantation systems $s^{5,9}$. With its wide range of species types and species combinations, including mixtures, our study provides a broad test of $\mathrm{CO}_{2} \times \mathrm{N}$ interactions under contrasting but relatively low $\mathrm{N}$ supply rates, and includes measurements of root biomass, whereas previous studies have been in a limited range of species monocultures with higher rates of $\mathrm{N}$ addition, and included no below-ground biomass measures ${ }^{5,9}$. In a two-year manipulation of $\mathrm{CO}_{2} \times \mathrm{N}$ in a 15-year-old pine plantation, wood production increased with elevated $\mathrm{CO}_{2}$ with a $\mathrm{N}$ addition of $11 \mathrm{~g} \mathrm{~N} \mathrm{~m}^{-2} \mathrm{yr}^{-1}$ but not under ambient $\mathrm{N}$ conditions ${ }^{5}$. In a long-term study in a highly managed pasture ${ }^{9}$, harvestable above-ground biomass in Lolium monocultures increased by more than $150 \mathrm{~g} \mathrm{~m}^{-2} \mathrm{yr}^{-1}$ with elevated $\mathrm{CO}_{2}$ when $\mathrm{N}$ addition was $56 \mathrm{~g} \mathrm{~N} \mathrm{~m}^{-2} \mathrm{yr}^{-1}$ but did not increase when $\mathrm{N}$ addition was $14 \mathrm{~g} \mathrm{~N} \mathrm{~m}^{-2} \mathrm{yr}^{-1}$. 
Table 1 | Repeated-measures analysis of variance of $\mathrm{CO}_{2}$ and $\mathrm{N}$ effects

\begin{tabular}{|c|c|c|c|c|c|c|}
\hline \multirow[t]{2}{*}{ Effect } & \multicolumn{2}{|c|}{$\begin{array}{l}\text { Total biomass } \\
\left(\mathrm{g} \mathrm{m}^{-2}\right)\end{array}$} & \multicolumn{2}{|c|}{$\begin{array}{l}\text { Total plant N } \\
\left(\mathrm{g} \mathrm{m}^{-2}\right)\end{array}$} & \multicolumn{2}{|c|}{$\begin{array}{c}\text { Net soil N } \\
\text { mineralization } \\
\left(\mathrm{mg} \mathrm{kg}^{-1} \mathrm{~d}^{-1}\right)\end{array}$} \\
\hline & $F$ & $P>F$ & $F$ & $P>F$ & $F$ & $P>F$ \\
\hline $\mathrm{CO}_{2}$ & 11.1 & 0.0288 & 52.95 & 0.160 & 0.01 & 0.9303 \\
\hline & 46.77 & $<0.0$ & 77.90 & $<0.0$ & 1.55 & 0.2141 \\
\hline Ye & 471.52 & & 187 & & 7.06 & 0.0080 \\
\hline $\mathrm{CO}_{2} \times$ year & 0.01 & 0.9283 & 11.68 & 0.0 & 3.64 & 0.0566 \\
\hline$N \times$ year & 9.84 & 0.0017 & 1.46 & 0.2264 & 1.23 & 0.2671 \\
\hline $\mathrm{CO}_{2} \times \mathrm{N}$ & 0.38 & 0.5356 & 0.01 & 0.91 & 1.10 & 0.2963 \\
\hline $\mathrm{CO}_{2} \times \mathrm{N} \times$ year & 10.35 & 0.00 & 3.86 & 0.0 & 4.25 & 0.0394 \\
\hline Diversity & 133.25 & $<0.0001$ & 75.57 & $<0.0001$ & 16.21 & $<0.0001$ \\
\hline Whole-model $R^{2}$ & 0.58 & $<0.0001$ & 0.40 & $<0.0001$ & 0.21 & $<0.0001$ \\
\hline
\end{tabular}

Effects of year, $\mathrm{CO}_{2}, \mathrm{~N}$ and diversity, and all interactions, on total biomass (above-ground plus $0-20 \mathrm{~cm}$ below-ground), total plant $\mathrm{N}$ per unit ground area, and net soil $\mathrm{N}$

mineralization rate are shown. Year is included in the model as a continuous variable.

Diversity was a significant main effect in all analyses but it did not influence the $\mathrm{CO}_{2} \times \mathrm{N}$ interaction $\left(\mathrm{CO}_{2} \times \mathrm{N} \times\right.$ diversity, $\left.P \geq 0.4\right)$ or the year $\times \mathrm{CO}_{2} \times \mathrm{N}$ interaction

$\left(\mathrm{CO}_{2} \times \mathrm{N} \times\right.$ year $\times$ diversity, $\left.P \geq 0.4\right)$. Interaction terms including diversity effects are

therefore not shown above, and effects of year, $\mathrm{CO}_{2}$ and $\mathrm{N}$ are shown pooled across

diversity treatments in Fig. 1 and Supplementary Information. Significant effects $(P \leq 0.05)$

are shown in bold text.

Findings from both of these studies are consistent with our results, indicating that the overarching control on responses to elevated $\mathrm{CO}_{2}$ by C:N supply stoichiometry might be comparable in intensive agricultural, forest plantation and natural ecosystems, although the $\mathrm{N}$ levels required to alleviate $\mathrm{N}$ limitation in agricultural systems may be an order of magnitude higher than in unmanaged vegetation. Given that the levels in our $\mathrm{N}$ treatments (ambient and $+4 \mathrm{~g} \mathrm{~N} \mathrm{~m}^{-2} \mathrm{yr}^{-1}$ ), and their difference, were within the global range of variation of both natural soil $\mathrm{N}$ availability and of atmospheric $\mathrm{N}$ deposition ${ }^{13,24}$, the results indicate that variabilities in soil $\mathrm{N}$ and in atmospheric $\mathrm{N}$ deposition are both likely to influence terrestrial ecosystem responses to elevated $\mathrm{CO}_{2}$. In sites with lowto-moderate soil $\mathrm{N}$ availability, $\mathrm{N}$ limitation probably constrains the stimulation of biomass accumulation by elevated $\mathrm{CO}_{2}$. In soils that are $\mathrm{N}$-rich and in regions with very high levels of $\mathrm{N}$ deposition, such limitation of the $\mathrm{CO}_{2}$ fertilization effect by insufficient $\mathrm{N}$ may be weak or absent.

Our results are consistent with the idea $^{7}$ that although some models indicate a considerable capacity of land ecosystems to sequester large amounts of $\mathrm{C}$ in the coming century ${ }^{1}$, this $\mathrm{C}$ accumulation is likely to be constrained over time by $\mathrm{N}$ availability ${ }^{7,8}$. Moreover, predictions of global $\mathrm{C}$ and $\mathrm{N}$ dynamics, and policy and political decisions whose efficacy rests on such predictions, should incorporate the impacts of multiple global change factors such as anthropogenic fertilization with $\mathrm{C}$ and $\mathrm{N}$, as well as the interactions between these and other global factors. Estimating the role of terrestrial ecosystems as current and future carbon sinks hinges on the ability to understand the biogeochemical consequences of variability in soil $\mathrm{N}$ limitations and $\mathrm{N}$ deposition rates worldwide.

\section{METHODS}

In our experiment (called BioCON) we grew 296 field plots (each $2 \mathrm{~m} \times 2 \mathrm{~m}$ ) containing different numbers and combinations of perennial grassland species under ambient and elevated atmospheric $\mathrm{CO}_{2}$ and with either ambient or enriched soil $\mathrm{N}$ supply ${ }^{18,25}$. Plots were arranged in six circular 20-m diameter rings at the Cedar Creek Natural History Area in central Minnesota, USA. In three elevated- $\mathrm{CO}_{2}$ rings, a free-air $\mathrm{CO}_{2}$ enrichment system ${ }^{18}$ was used during each growing season to maintain the $\mathrm{CO}_{2}$ concentration at an average of $560 \mu \mathrm{mol} \mathrm{mol}^{-1}$, a concentration likely to be reached this century. Three ambient $\mathrm{CO}_{2}$ rings were treated identically but without additional $\mathrm{CO}_{2}$. Half of the plots in each ring received $\mathrm{N}$ amendments of $4 \mathrm{~g} \mathrm{~N} \mathrm{~m}^{-2} \mathrm{yr}^{-1}$ applied as $\mathrm{NH}_{4} \mathrm{NO}_{3}$ on three dates each year. The treatments were arranged in complete factorial combination of two levels of atmospheric $\mathrm{CO}_{2}$ (ambient and elevated), four levels of plant species richness (1, 4, 9 and 16) and two levels of $\mathrm{N}$ (ambient and enriched with added N) (see Supplementary Information and refs 18, 25 for further detail). There were $32,15,15$ and 12 plots with $1,4,9$ and 16 species, respectively, at each of the four contrasting $\mathrm{CO}_{2}$ and $\mathrm{N}$ levels $(n=296$ plots in all). The 16 study species included four $\mathrm{C}_{4}$ grasses (Andropogon gerardii, Bouteloua gracilis, Schizachyrium scoparium and Sorghastrum nutans), four $\mathrm{C}_{3}$ grasses (Agropyron repens, Bromus inermis, Koeleria cristata and Poa pratensis), four $\mathrm{N}$-fixing legumes (Amorpha canescens, Lespedeza capitata, Lupinus perennis and Petalostemum villosum) and four non-leguminous forb species (Achillea millefolium, Anemone cylindrica, Asclepias tuberosa and Solidago rigida).

Each year in every plot we assessed both above-ground and below-ground $(0-20 \mathrm{~cm})$ plant biomass (in both June and August) and plant $\mathrm{C}$ and $\mathrm{N}$ concentrations (in August only) ${ }^{18,25}$. Above-ground biomass was harvested by clipping a $10 \mathrm{~cm} \times 100 \mathrm{~cm}$ strip just above the soil surface. Total below-ground biomass (fine roots, coarse roots and crowns) was sampled at $0-20 \mathrm{~cm}$ depth with the use of three cores $5 \mathrm{~cm}$ in diameter. Soil net $\mathrm{N}$ mineralization rates were measured in situ each year in each plot by using a semi-open core one-month incubation ${ }^{18}$ beginning in late June. We examined results for the entire period 1998-2003 and used a repeated-measures analysis of variance to test for the main effects of $\mathrm{CO}_{2}, \mathrm{~N}$ and diversity and their interactions, and whether these changed with year.

\section{Received 10 October; accepted 29 November 2005}

1. Intergovernmental Panel on Climate Change. Climate Change 2001: The Scientific Basis (Cambridge Univ. Press, New York, 2001).

2. Rastetter, E. B., Agren, G. I. \& Shaver, G. R. Responses of N-limited ecosystems to increased $\mathrm{CO}_{2}$ : a balanced-nutrition coupled-element-cycles model. Ecol. Appl. 7, 444-460 (1997).

3. McMurtrie, R. E., Dewar, R. C., Medlyn, B. E. \& Jeffreys, M. P. Effects of rising $\mathrm{CO}_{2}$ on growth and carbon sequestration in forests: a modelling analysis of the consequences of altered litter quantity and quality. Plant Soil 224, 135-152 (2000)

4. Zak, D. R., Pregitzer, K. S., Curtis, P. S. \& Holmes, W. E. Atmospheric $\mathrm{CO}_{2}$ and the composition and function of soil microbial communities. Ecol. Appl. 10, 47-59 (2000).

5. Oren, R. et al. Soil fertility limits carbon sequestration by forest ecosystems in a $\mathrm{CO}_{2}$ enriched world. Nature 411, 469-472 (2001).

6. Shaw, M. R. et al. Grassland responses to global environmental changes suppressed by elevated $\mathrm{CO}_{2}$. Science 298, 1987-1990 (2002).

7. Hungate, B. A., Dukes, J. S., Shaw, M. R., Luo, Y. Q. \& Field, C. B. Nitrogen and climate change. Science 302, 1512-1513 (2003).

8. Luo, Y. et al. Progressive nitrogen limitation of ecosystem responses to rising atmospheric carbon dioxide. Bioscience 54, 731-739 (2004)

9. Schneider, M. K. et al. Ten years of free-air $\mathrm{CO}_{2}$ enrichment altered the mobilization of $\mathrm{N}$ from soil in Lolium perenne L. swards. Glob. Change Biol. 10, 1377-1388 (2004).

10. Lloyd, J. \& Farquhar, G. D. The $\mathrm{CO}_{2}$ dependence of photosynthesis, plant growth responses to elevated atmospheric $\mathrm{CO}_{2}$ concentrations, and their interactions with soil nutrient status. I. General principles and forest ecosystems. Funct. Ecol. 10, 4-32 (1996)

11. Peterson, A. G. et al. The photosynthesis-leaf nitrogen relationship at ambient and elevated atmospheric carbon dioxide: a meta-analysis. Glob. Change Biol. 5 331-346 (1999).

12. Zak, D. R., Holmes, W. E., Finzi, A. C., Norby, R. J. \& Schlesinger, W. H. Soil nitrogen cycling under elevated $\mathrm{CO}_{2}$ : a synthesis of forest face experiments. Ecol. Appl. 13, 1508-1514 (2003).

13. Vitousek, P. M. et al. Human alteration of the global nitrogen cycle: sources and consequences. Ecol. Appl. 7, 737-750 (1997).

14. Luo, Y. Field, C. B. \& Mooney, H. A. Predicting responses of photosynthesis and root fraction to elevated $\left[\mathrm{CO}_{2}\right]$ : interactions among carbon, nitrogen and growth. Plant Cell Environ. 17, 1195-1204 (1994).

15. Cannell, M. \& Thornley, J. N-poor ecosystems may respond more to elevated $\left[\mathrm{CO}_{2}\right]$ than $\mathrm{N}$-rich ones in the long term. A model analysis of grassland. Glob. Change Biol. 4, 431-442 (1998).

16. Gill, R. A. et al. Nonlinear grassland responses to past and future atmospheric $\mathrm{CO}_{2}$. Nature 417, 279-282 (2002)

17. Williams, M. A., Rice, C. W. \& Owensby, C. E. Carbon dynamics and microbia activity in tallgrass prairie exposed to elevated $\mathrm{CO}_{2}$ for 8 years. Plant Soil 227, 127-137 (2000)

18. Reich, P. B. et al. Plant diversity enhances ecosystem responses to elevated $\mathrm{CO}_{2}$ and nitrogen deposition. Nature 410, 809-812 (2001).

19. Finzi, A. C. \& Schlesinger, W. H. Soil-nitrogen cycling in a pine forest exposed to 5 years of elevated carbon dioxide. Ecosystems 6, 444-456 (2003).

20. Owensby, C. E., Auen, L. M. \& Coyne, P. I. Biomass production in a nitrogen fertilized, tallgrass prairie ecosystem exposed to ambient and elevated levels of $\mathrm{CO}_{2}$. Plant Soil 165, 105-113 (1994)

21. Zanetti, $\mathrm{S}$. et al. Does nitrogen nutrition restrict the $\mathrm{CO}_{2}$ response of fertile grassland lacking legumes? Oecologia 112, 17-25 (1997)

22. Zak, D. R., Pregitzer, K. S., Curtis, P. S. \& Holmes, W. E. Atmospheric $\mathrm{CO}_{2}$ and the composition and function of soil microbial communities. Ecol. Appl. 10, 47-59 (2000). 
23. Reich, P. B. et al. Species and functional diversity independently influence biomass accumulation and its response to $\mathrm{CO}_{2}$ and N. Proc. Natl Acad. Sci. USA 101, 10101-10106 (2004).

24. Galloway, J. N. et al. The nitrogen cascade. Bioscience 53, 341-356 (2003).

25. Reich, P. B. et al. Do species and functional groups differ in acquisition and use of $\mathrm{C}, \mathrm{N}$ and water under varying atmospheric $\mathrm{CO}_{2}$ and $\mathrm{N}$ availability regimes? A field test with 16 grassland species. New Phytol. 150, 435-448 (2001).

26. Lee, T. D., Tjoelker, M. G., Ellsworth, D. S. \& Reich, P. B. Leaf gas exchange responses of 13 prairie grassland species in the field under elevated carbon dioxide and increased nitrogen supply. New Phytol. 150, 405-418 (2001).

27. Craine, J. M., Wedin, D. A. \& Reich, P. B. The response of soil $\mathrm{CO}_{2}$ flux to changes in atmospheric $\mathrm{CO}_{2}$, nitrogen supply, and plant diversity. Glob. Change Biol. 7, 947-953 (2001)

28. Dijkstra, F., Hobbie, S., Reich, P. \& Knops, J. Divergent effects of elevated $\mathrm{CO}_{2}$, $\mathrm{N}$ fertilization, and plant diversity on soil $\mathrm{C}$ and $\mathrm{N}$ dynamics in a grassland field experiment. Plant Soil 272, 41-52 (2005).

29. Lüscher, A., Hartwig, U. A., Suter, D. \& Nösberger, J. Direct evidence that in fertile grassland symbiotic $\mathrm{N}_{2}$ fixation is an important trait for a strong response of plants to elevated atmospheric $\mathrm{CO}_{2}$. Glob. Change Biol. 6, 655-662 (2000)

30. Hungate, B. A. et al. $\mathrm{CO}_{2}$ elicits long-term decline in nitrogen fixation. Science 304,1291 (2004)
Supplementary Information is linked to the online version of the paper at www.nature.com/nature.

Acknowledgements We thank the US Department of Energy Program for Ecosystem Research, the National Science Foundation Long-Term Ecological Research and Biocomplexity Coupled Biogeochemical Cycles Programs, and the University of Minnesota for supporting this research.

Author Contributions All authors were involved in the design or implementation of the experiment, or both, with P.B.R. having the major responsibility for these. P.B.R., D.E., D.T., J.K. and S.N. were involved in the initial experimental design. J.T. was responsible for a substantial fraction of the experimental management and data collection, with smaller contributions in this area from T.L., D.E., J.B.W., J.K. and S.H. P.B.R. performed the statistical analyses and wrote the paper, with assistance from S.H., T.L., D.E., S.N. and J.B.W. All authors discussed the results and commented on the manuscript.

Author Information Reprints and permissions information is available at npg.nature.com/reprintsandpermissions. The authors declare no competing financial interests. Correspondence and requests for materials should be addressed to P.B.R. (preich@umn.edu). 